\title{
新潟県松之山地すべり地域の地下水の水質について
}

\section{Chemical Characteristics of Groundwaters from the Matsunoyama Landslide Area, Niigata Prefecture}

\author{
渡 部 直 喜* \\ Naoki WATANABE \\ 熟 津 史 也** \\ 大 木 靖 衛*** \\ Fuminari WASHIZU \\ Yasue OKI \\ 修*** \\ Osamu SATo
}

\begin{abstract}
The Matsunoyama landslides at the southern Niigata Prefecture have long been manifesting a lot of slumps and occasionally earthflows intermittently. The landslides occupy on a dome of Tertiary sediments composed of thick dacitic tuff and mudstone. Various landslide controls, such as drilling of collecting wells, have been made since 1962 areal slumping which destructed many houses, roads and firm yards.

Groundwater samples were collected from collecting wells, horizontal and perpendicular drill holes and springs. Some of the groundwaters discharged in the landslide are unusually high in dissolved materials and warm in temperature suggesting them as deep thermal origin. Following five types of ground waters, Ca- $\mathrm{HCO}_{3}$ type, $\mathrm{Na}-\mathrm{HCO}_{3}$ type, $\mathrm{Ca}-\mathrm{SO}_{4}$ type, $\mathrm{Na}-\mathrm{SO}_{4}$ type and $\mathrm{Na}-\mathrm{Cl}$ type are chemically recognized in the Matsunoyama landslides. $\mathrm{Ca}-\mathrm{HCO}_{3}$ type distributes at head to middle of the landslide mass. $\mathrm{Na}-\mathrm{HCO}_{3}$ type predominates at foot of the landslide. $\mathrm{Ca}-\mathrm{SO}_{4}$ type and $\mathrm{Na}_{-} \mathrm{SO}_{4}$ type find at head to middle and foot of the landslide in mudstone area, respectively. $\mathrm{Ca}$ is major dissolved in the tuff area. In the mudstone area, $\mathrm{Na}$ is major dissolved and $\mathrm{SO}_{4}$ is a characteristic constituent. $\mathrm{Ca}^{2+}$ is exchanged with $\mathrm{Na}^{+}$from $\mathrm{Na}$-rich clay minerals during migration from head to foot in subsurface of landslides. Na-rich clay minerals dominate in the mudstone rather than tuff. $\mathrm{SO}_{4}$ is supplied from oxidation of pyrite included mudstone. High concentration of $\mathrm{Na}-\mathrm{HCO}_{3}$ is produced under at high $\mathrm{CO}_{2}$ partial pressure and reductive conditions. $\mathrm{Na}-\mathrm{Cl}$ type waters and warm waters are influenced by the deep geopressured hydrothermal system.
\end{abstract}

キーワード：松之山地すべり，地すべり，地下水，水質，

\section{1.はじめに}

地すべりの発生が地下水の動きに支配されていること は広く認められている。地下水の水質は, 形成場の環境 条件や接していた岩石の性質をよく反映するので，水質 と母岩の造岩鉱物種や地質構造, 水温などの情報と組み 合わせることによって水文地質条件を推定する良い指標 となり得る。水質, 水温, 地質などの情報を整理し, そ れらの相関を調べ, 基本的な水一岩石相互作用を理解すれ ば, 排水している地下水がどのような形成過程を経てき た水か識別することが可能となる。こうした研究の蓄積 は, 地すべりの調査, 防止・排水工事に役立つ。

新潟県の中部から南西部にかけての丘陵地には, いわ ゆる第三紀層地すべりとよばれる大小さまざまな地すべ りが数多く発生している。調査地域である新潟県東頸城

* 新潟大学大学院自然科学研究科

$* *$ 新潟県安塚町役場

**** 新潟大学櫴雪地域災害研究センター
郡松之山地域の地すべりの基岩は主として酸性疑灰岩と 泥岩であり, 母岩の違いが地下水の水質にどのように反 映されるか, といった水一岩石相互作用の研究には最適で ある。また, $\mathrm{Na}-\mathrm{Cl}$ 型の特異な地下水もみられる。 本論文では, 地すべり地地下水の水質の特徵と分布を 明らかにし，地質情報と組み合わせることによって，水 一岩石相互作用の立場から複雑な地すべり地地下水の水 質の解析を試みた。

\section{2. 調査地域の概要}

新潟県東頸城郡松之山町は総面積が 8649 ha, 県南西 部に位置する（図-1）。松之山町の地すべりは, 主とし て大松山（標高 $674.0 \mathrm{~m}$ ) を中心とする松之山ドーム構造 の地域に分布している。松之山町内において国の指定す る地すべり防止指定区域は, 1988 年 4 月現在, 建設省所 管 13 地区 (面積 $1322.43 \mathrm{ha}$ ), 林野庁所管 15 地区 (面積 $2022.29 \mathrm{ha}$ ), 農林水産省所管 4 地区（面積 $510.76 \mathrm{ha）}$ であり,その総面積は町の約半分を占める。昭和 37 年に 


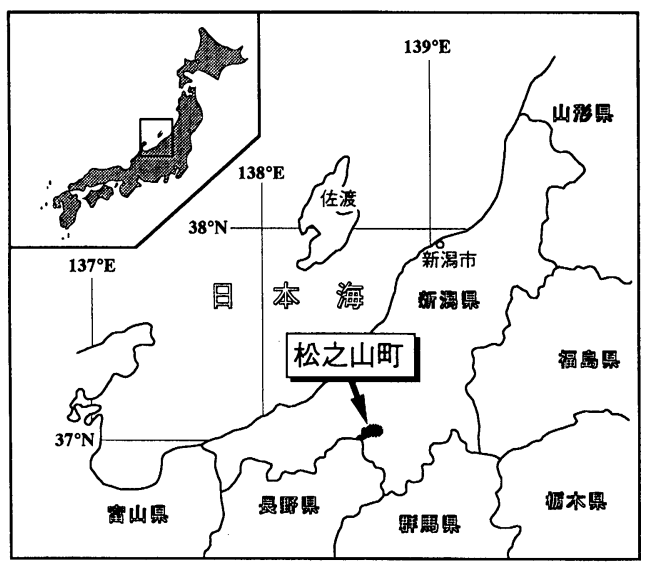

図-1 調査地域の位置図

発生した松之山地すべりは約 850 ha にも達する大規模 なもので, 家屋, 道路, 耕地等に多大な被害を与えた。 本地域は毎年のように大小の地すべりが発生し続ける, 全国でも有数の地すべり多発地帯となっている。

\section{3 . 調査地域の地形と地質}

松之山町の地形は, 大部分が東頸城丘陵とよばれる標 高 250 ～ $800 \mathrm{~m}$ の丘陵地からなる。丘陵地より流れ出る 河川の流系の解析によれば, その地形は松之山背斜と呼 ばれる大松山付近を中心に北東一南西方向に長軸をもつ ドーム構造に規制されているとみられる。大局的には背 斜部が丘陵を形成し，河川は向斜部を流れ，また丘陵を なすドーム構造をとりまく楕円形の走向線に沿って流れ
ている。丘陵地には新旧さまざまな地すべりによって形 成された緩傾斜地や平坦面がいたるところにある。大松 山をドーナツ状にとりまいて分布する緩傾斜地や平坦面 は, 主に水田に利用されている。南縁部は $1000 \mathrm{~m}$ 級の 山々からなる関田山脈で境されている。南西縁の大厳寺高 原付近の緩傾斜地や平坦面は土石流によって形成された。 本地域の地質は主として新第三系からなり，下位より 松之山層, 黒倉層, 東川層が重なり, その上位には松之 山背斜北西翼では奈良立層が, 南西翼では魚沼層群が重 なる(図ー2)。地質の詳細については天野1), 津田ほか2) の報告がある。地すべりは主として松之山層と黒倉層の 分布する地域で発生している。ここでは, 地すべり地の 水質形成に関与する松之山層と黒倉層の岩相についての み簡単に述べることにする。

松之山層は主として緑灰色の安山岩〜デイサイト質粗 粒凝灰岩, 軽石質凝灰岩からなり, 層厚は $250 \mathrm{~m}+$ であ る。本凝灰岩は, しばしば $10 \sim 100 \mathrm{~cm}$ の硬質頁岩層を挟 在する。初生鉱物は石英, 黒雲母, 普通輝石, 斜長石で あるが, そのほとんどは変質作用によってスメクタイト (粘土), 沸石, 雲母類, および少量の炭酸塩鉱物（方解 石，ドロマイト）などの二次鉱物に置き換わっている。

黒倉層は暗灰色泥岩を主体とし, 層厚は 600〜800 m である。泥岩中には砂岩の薄層や鍵層となる凝灰岩層が 挟在される。黒倉層分布地域の南西部においては, 砂岩 層が局所的に卓越する。暗灰色泥岩を構成する鉱物は, 大部分がスメクタイトであり, 少量の石英, 斜長石, 緑 泥石, イライト, 極少量の黄鉄鉱, ドロマイトを含む。

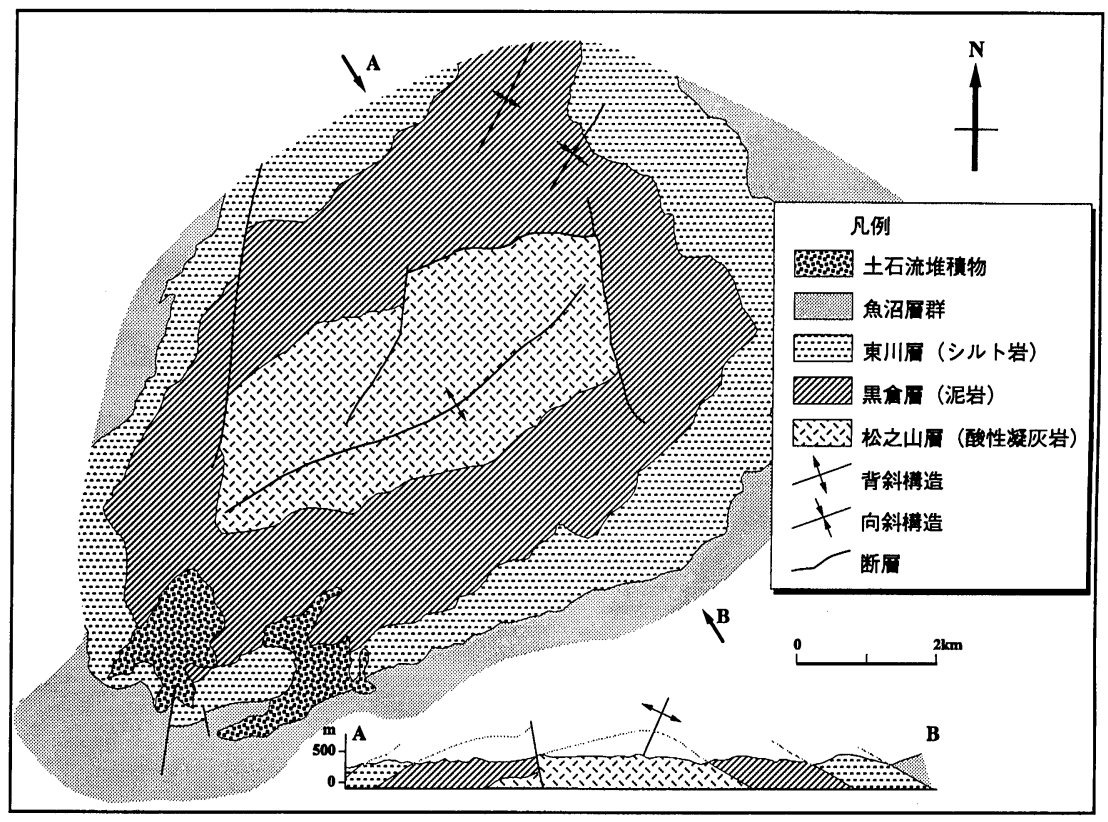

図－2 松之山地域の地質図(天野，1991 を一部簡略化） 


\section{4. 水の採取と分析}

昭和 37 年に発生した松之山地すべり以来の対策・防止 工事によって, 本調査地域内には集水井や横孔ボーリン グなどが 200 以上ある。本調査地域で分析した水は, 集 水井と横孔ボーリングからの排水, 調査用ボーリング孔 内水および自然湧泉水である。比較のため調查地域内の 家庭用井戸水, 池・河川水, および温泉水も採水した。 採取した水は合計 180 試料である。野外調査地域は松之 山町内の地すべり防止指定区域のほほ全域である。野外 調查と水の採取は 1991 年と 1992 年におこなった。水の 処理, 分析の概要は次の通りである。

現地で採取した水は $250 \mathrm{ml}$ のポリエチレン瓶 2 本に 保存した。同時に $\mathrm{H}_{4} \mathrm{SiO}_{4}$ および $\mathrm{Fe}^{2+}$ 分析用試料 $5 \mathrm{ml}$ をそれぞれ $50 \mathrm{ml}$ のポリエチレン瓶にとり, 採取後ただ ちに試薬で発色させたのち，これらを実験室に持ち帰っ て定量した。現地においては, 採水時の気温, 水温, 電 気伝導度, $\mathrm{pH}$ を測定した。 $\mathrm{HCO}_{3}{ }^{-}$の分析は採水当日に 宿舎でおこなった。

分析項目，分析方法は次の通りである。

水温・気温;アルコールおよび水銀棒温度計による測 定。

電気伝導度; 携帯型電気伝導度計 (堀場製)による測定 $\left(25^{\circ} \mathrm{C}\right.$ に換算)。

$\mathrm{pH}$; 比色法および携带型 $\mathrm{pH}$ 計（横河製）による測定 ( $25^{\circ} \mathrm{C}$ に換算)。

$\mathrm{HCO}_{3}{ }^{-}$; メチルオレンジを指示薬として, 中和滴定に よるアルカリ度（酸消費量）を $\mathrm{HCO}_{3}^{-}$とした。 $\mathrm{H}_{4} \mathrm{SiO}_{4}$; モリブデン青吸光光度法 (JIS K 0101, 1986)。

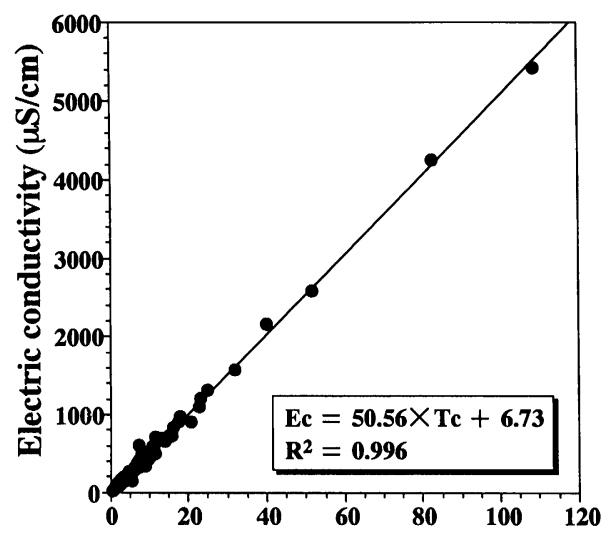

Total concentration (meq/l)

图-3 全当量濃度 $\mathrm{Tc}(\mathrm{meq} / \mathrm{l})$ と電気伝導度 $\mathrm{Ec}(\mu \mathrm{S} / \mathrm{cm}$; $\left.25^{\circ} \mathrm{C}\right)$ の関係
$\mathrm{Fe}^{2+} ; \mathrm{O}$-フェナントロリン吸光光度法（JIS K 0102, 1986)。

$\mathrm{Na}^{+}, \mathrm{NH}_{4}{ }^{+}, \mathrm{K}^{+}, \mathrm{Mg}^{2+}, \mathrm{Ca}^{2+}, \mathrm{Cl}^{-}, \mathrm{NO}_{3}{ }^{-}, \mathrm{SO}_{4}{ }^{2-}$ の各イオン; 液体クロマトグラフ (島津製)により分 析。

なお，今回分析した水の電解質の全当量濃度 (meq/l) と電気伝導度の間には当然のことながら高い相関がある (図一3)。この関係を利用すれば，電気伝導度 $(\mu \mathrm{S} / \mathrm{cm})$ を測定し,その值を 50 で割った值が電解質のおよその全 当量濃度となる。

\section{5 . 地すべり地地下水の水一岩石相互作用}

地すべり地の地下水の水質は, 地下水と造岩鉱物の水 一岩石相互作用によって形成される。詳細については Garrels and Christ ${ }^{3)}$ の教科書や佐藤 ${ }^{45) 6)}$ や吉岡 ${ }^{7) 8)}$ の解 説，吉岡・金井 ${ }^{9)}$ を参照していただきたい。新潟県の第三 紀層地すべり地における地下水の水質の形成過程は単純 化すると, 酸の供給と酸と鉱物の反応に大別できる。酸 としては $\mathrm{H}_{2} \mathrm{CO}_{3}$ または $\mathrm{HCO}_{3}{ }^{-}$と $\mathrm{H}_{2} \mathrm{SO}_{4}$ の供給を考え る必要がある。供給された酸は炭酸塩を溶解し, ケイ酸 塩を不均一溶解して粘土などを形成する。陽イオンの量 比の変動には，粘土鉱物による陽イオン交換が大きな役 割を果たしている。地すべり地では主に以下に示す項目 の水-岩石相互作用を考えればよい。

1) $\mathrm{CO}_{2}$ ガスによるケイ酸塩鉱物の不均一溶解反応。 ケイ酸塩鉱物の溶解量は, $\mathrm{CO}_{2}$ ガスの供給量, つまり地 下水と平衡にあるガスの $\mathrm{CO}_{2}$ 分圧に依存する。1 種類の ケイ酸塩だけからなる単純な系では, その鉱物に飽和す るまで溶解反応は進む。天然の岩石は多種の鉱物で構成 されており，系は複雑である。

2 ) $\mathrm{CO}_{2}$ ガスによる炭酸塩鉱物（方解石など）の溶解 反応。炭酸塩鉱物の溶解もケイ酸塩鉱物の場合と同様に 地下水と平衡なガスの $\mathrm{CO}_{2}$ 分圧に依存している。方解石 だけからなる単純な系では, 反応は方解石に飽和するま で進む。

3 ）粘土鉱物による陽イオン交換反応。陽イオンの吸 着力は,

$$
\mathrm{Ca}^{2+}>\mathrm{Mg}^{2+} \fallingdotseq \mathrm{NH}_{4}{ }^{+}>\mathrm{K}^{+}>\mathrm{Na}^{+}
$$

であるので, $\mathrm{Ca}^{2+}$ と $\mathrm{Na}^{+}$について見てみると,

$\mathrm{Na}$ 型粘土 $+\mathrm{Ca}^{2+} \rightarrow \mathrm{Ca}$ 型粘土 $+2 \mathrm{Na}^{+}$

となり, 水の中の $\mathrm{Ca}^{2+}$ は $\mathrm{Na}$ 型粘土に吸着して $\mathrm{Ca}$ 型粘 土となり， $\mathrm{Na}^{+}$を放出する。ただし，イオン交換反応は 地下水中の陽イオンの量比 $\left(\mathrm{Ca}^{2+} / \mathrm{Na}^{+}\right.$比, $\mathrm{Ca}^{2+} / \mathrm{Mg}^{2+}$ 比等）の変動は説明できるが, 溶存物質量（当量濃度） の変化とは無関係である。 
4 ）硫化鉱物（黄鉄鉱など）の酸化反応。黄鉄鉱が酸 化されると $\mathrm{H}^{+}$と $\mathrm{SO}_{4}{ }^{2-}$ が生成する。さらに酸素の供給 がある場合, $\mathrm{Fe}^{2+}$ は $\mathrm{Fe}^{3+}$ に酸化されて褐鉄鉱（ $\mathrm{FeO}$ ・ $\left.\mathrm{OH} \cdot \mathrm{nH}_{2} \mathrm{O}\right)$ となり, 沈殿する。また, $\mathrm{H}^{+}$は他のケイ酸 塩鉱物や炭酸塩鉱物との反応によっても消費される。こ れらの酸化反応は酸素の供給が多い地表近くで進行する。

5 ）有機物による硫酸イオンの還元反応。 $\mathrm{SO}_{4}{ }^{2-}$ は有 機物によって還元され，硫化鉄や硫化水素を生じる。逆 に, 有機物は酸化され $\mathrm{HCO}_{3}{ }^{-}$となる。結果として, 水質 は $\mathrm{SO}_{4}$ 型から $\mathrm{HCO}_{3}$ 型に変わる。この反応は酸素の供給 のない還元的条件下，つまり地下深くで進行する。還元 剤には 2 種類あると考えられる。一つは，地すべりの活 動によって地下に埋没した樹木や腐植物であり，もう一 つは初生的に砂岩や泥岩といった堆積岩に含まれる有機 物である。

\section{6. 結果と考察}

\section{1 水質の特徵と分布}

松之山地域には主としてデイサイト質凝灰岩と泥岩が 分布し, 岩相の違いは水質の違いによく反映されている。 図-4に凝灰岩地域と泥岩地域に産する地下水の水質別 の割合を円グラフに示した。陰イオンに注目すると，凝 灰岩地域はほとんどが $\mathrm{HCO}_{3}$ 型なのに対して, 泥岩地域

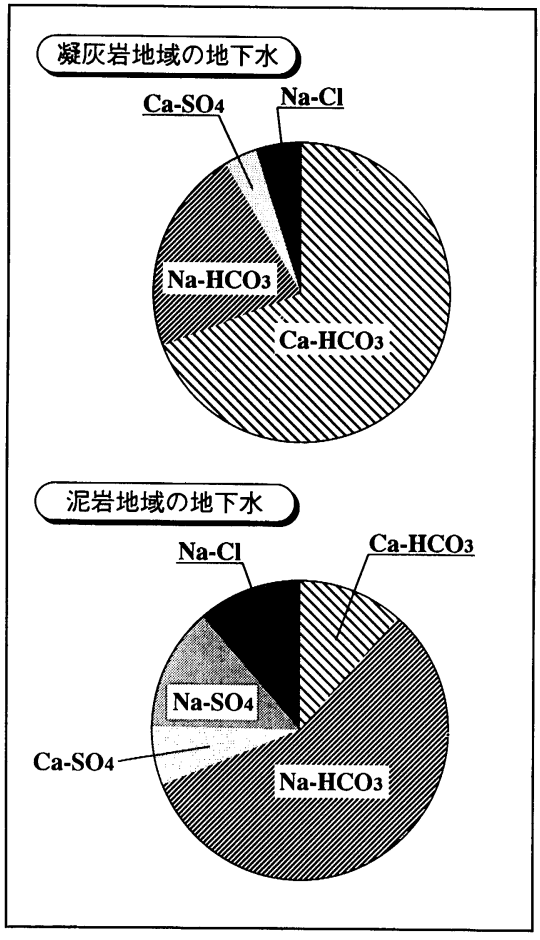

図-4 凝灰岩地域と泥岩地域の地下水に占める 各タイプの水質の割合
では $\mathrm{SO}_{4}$ 型の割合が大きくなる。これは先に述べた硫化 鉱物の酸化反応によって, 泥岩に含まれる黄鉄鉱が酸化 され, $\mathrm{SO}_{4}{ }^{2-}$ を生成したためである。また, 凝灰岩地域と 泥岩地域の $\mathrm{HCO}_{3}$ 型と $\mathrm{SO}_{4}$ 型地下水それぞれの陽イオ ンに注目すると, 凝灰岩地域では $\mathrm{Ca}$ 型の割合が大きく, 泥岩地域では $\mathrm{Na}$ 型の割合が大きい。さらに両地域の水 質を比較するため, $\mathrm{NaCl}$ 成分を取り除いた上で, 次式に よって主要な陽イオンである $\mathrm{Ca}^{2+}$ と $\mathrm{Na}^{+}$の合計に占 める $\mathrm{Ca}^{2+}$ と $\mathrm{Na}^{+}$の割合（\%）を求めた。図 -5 と図 -6 は，それらの頻度分布と組成範囲である。

$$
\mathrm{Ca}(\%)=100 \times\left[\mathrm{Ca}^{2+}\right] /\left\{\left[\mathrm{Ca}^{2+}\right]+2 \times\left[\mathrm{Na}^{+}\right]\right\}
$$

［］はモル濃度 $(\mathrm{mol} / \mathrm{l})$ である。

凝死岩地域と泥岩地域とでは陽イオン組成範囲や組成 分布にかなりの違いがある(図一5)。凝灰岩地域の Ca の 割合は $10 \%$ ～ $90 \%$ の範囲にあり, 最頻値は $70 \%$ ～ $80 \%$ に ある。泥岩地域の場合は Ca の割合は数\% 80\%の範囲 にあり, 最頻值は $40 \%$ ～ $0 \%$ にある。陽イオンの濃度と 組成を支配しているのは，岩石に含まれる鉱物の溶解反 応である。凝灰岩に含まれる黒雲母や普通輝石が完全に 変質鉱物に置き換えられていると仮定すると，最も溶解 度の大きい鉱物は斜長石である。方解石と共存している ので，斜長石の溶解は方解石に飽和するまで進行する。 方解石に飽和する前に斜長石が消費された場合，次に溶

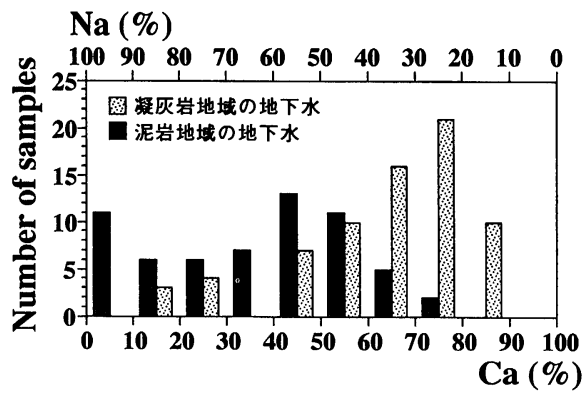

図-5 凝灰岩地域と泥岩地域の地下水における主陽イオン成 分 $(\mathrm{Ca}$ と $\mathrm{Na}$ ) に占める $\mathrm{Ca}$ 成分の割合 (\%)別の試料数

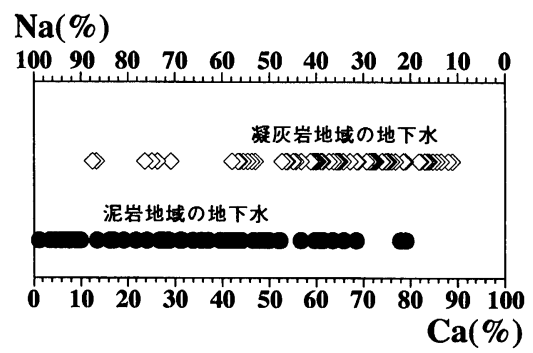

図-6 凝灰岩地域と泥岩地域の地下水における主陽イオン成 分 $(\mathrm{Ca}$ と $\mathrm{Na}$ ) に占める $\mathrm{Ca}$ 成分の割合 $(\%)$ の組成範囲 
解度の大きい方解石が溶解する。泥岩においても斜長石 が溶解し，方解石とドロマイトの違いはあるが, 凝灰岩 の場合とほほ同様の反応が生じる。溶出した陽イオンは, したがって Ca 成分に富む。ただし, 凝灰岩地域の地下水 と泥岩地域の地下水を比べると, 最も $\mathrm{Ca}$ 成分に富む水 の組成 $(\mathrm{Ca} / \mathrm{Na}$ 比) が異なり（図一6), 凝戻岩地域の水

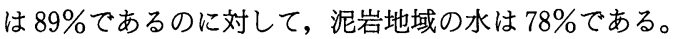
この違いの一つは溶解する鉱物の組成を反映していると 考えられる。凝灰岩と泥岩に含まれる斜長石の $\mathrm{Ca} / \mathrm{Na}$ 比は異なり，凝灰岩地域の斜長石の方が $\mathrm{Ca}$ 成分に富む 可能性が強い。しかし，図-5 のCa 成分の頻度分布は凝 灰岩地域の水と泥岩地域の水で大きく異なっており, こ れは溶解する斜長石の組成だけでは説明できない。この ような地すべり地の地下水における陽イオン比の変動は 粘土鉱物のイオン交換反応によって説明できる。凝灰岩 は $\mathrm{Ca}$ 型の粘土鉱物を多く含み, 泥岩は $\mathrm{Na}$ 型の粘土鉱 物を多く含むと考えられる。

松之山地すべり地域の全電解質当量濃度に対する水質 別の試料数の分布が図ー7である。横軸は 0 ～10 meq/1 末満は $1 \mathrm{meq} / 1$ ごとに $10 \sim 100 \mathrm{meq} / 1$ 未満は $10 \mathrm{meq} / 1$ ごとに目盛りを設定した。陽イオンに注目すると，低濃 度では $\mathrm{Ca}$ 型が多く, 高濃度では $\mathrm{Na}$ 型が多い。さらに注 目すべきは, $30 \mathrm{meq} / 1$ を超える異常に高い電解質濃度を 有する地下水はすべて $\mathrm{Na}-\mathrm{Cl}$ 型であるということであ る。実際には, $\mathrm{Na}-\mathrm{HCO}_{3}$ 型や $\mathrm{Na}-\mathrm{SO}_{4}$ 型に分類される 地下水であっても,電解質濃度の高いものの中には $\mathrm{Cl}$ 濃 度の高いものが存在している。

調査地域の一部である大松山の北東地域の地すべり地 地下水の水質と電気伝導度 $(\mu \mathrm{S} / \mathrm{cm})$ の分布を図 -8 に
示す。地すべり地形は空中写真の判読によるものである。 図一8をみると, 凝灰岩地域の地下水は $\mathrm{HCO}_{3}$ 型が多く, 泥岩地域には $\mathrm{SO}_{4}$ 型の割合が多い。このことは前に指摘 した通りである。 $\mathrm{HCO}_{3}$ 型地下水に注目すると $\mathrm{Ca}$ $\mathrm{HCO}_{3}$ 型の水は広範囲に分布しているが, $\mathrm{Na}-\mathrm{HCO}_{3}$ 型 の地下水の分布には偏りがある。地すべり地形と水質の 関係にはさまざまな要素が影響していて単純ではないが， 松之山地すべりでは大局的には頭部から中央部では $\mathrm{Ca}$ 型が多く，中央部から末端部に向かうにしたがって，Ca

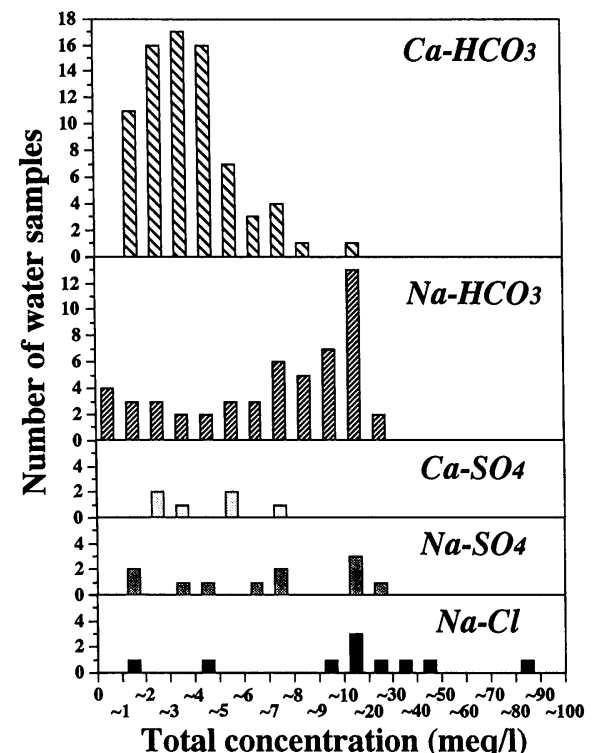

図ー7＼cjkstart地すべり地地下水の水質のタイプ別の全当量 濃度に対する試料数

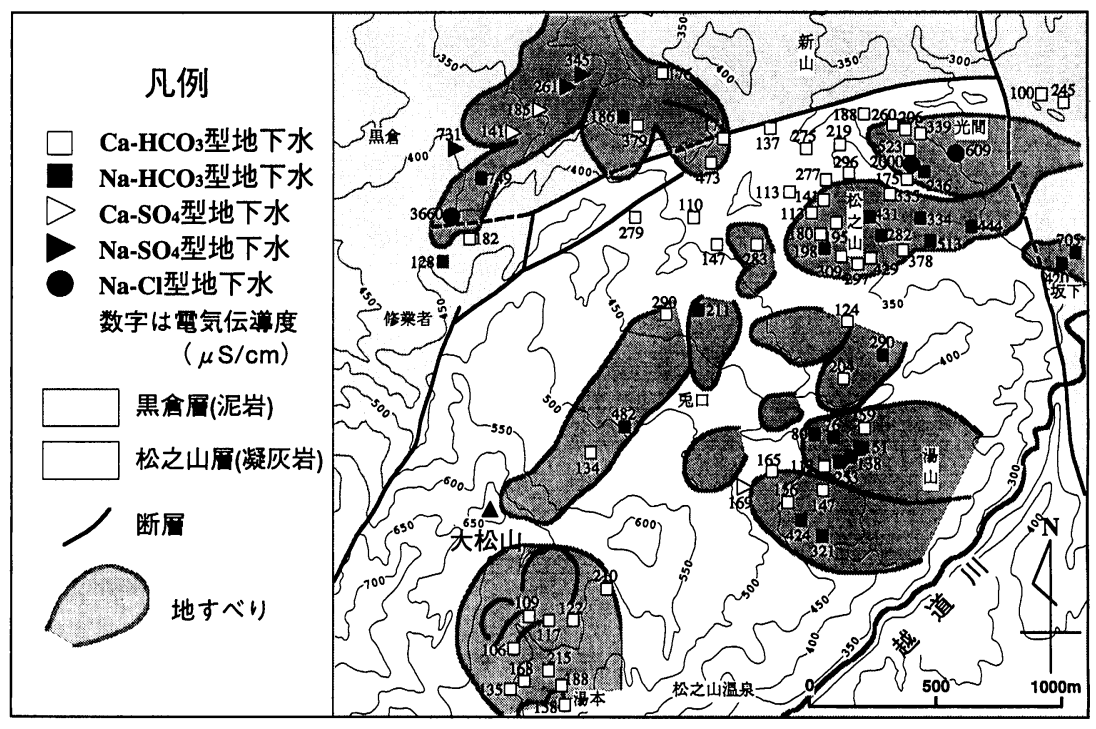

図ー8 大松山の北東地域の地すべり地地下水の水質のタイプ・電気伝導度分布 
型に比べ $\mathrm{Na}$ 型の出現する頻度が増加する傾向にある。 また,断層の近傍には $\mathrm{NaCl}$ 型地下水がみられる。全体と して Ca 型に比べ $\mathrm{Na}$ 型の方が電気伝導度, つまり電解 質濃度が高く, 図一7にみられた傾向と一致する。このこ とは主として地すべり頭部付近から侵入した地下水の $\mathrm{CO}_{2}$ 分圧と滞留時間に関係があることを示唆している。 地下に浸透後間もない地下水は電解質濃度が低く, 時間 の経過とともに岩石との反応によって $\mathrm{CO}_{2}$ ガスを消費 しながら反応が進行し, 濃度が増加する。これと平行し て, $\mathrm{Ca}^{2+}$ は $\mathrm{Na}$ 型粘土によるイオン交換反応によって $\mathrm{Na}^{+}$に置き換えられる。前述のように造岩鉱物の溶解度 は, $\mathrm{CO}_{2}$ 分圧に規制されている。地下水の電解質濃度 は, いかに滞留時間が長いとしてもその濃度には限界が あり, $\mathrm{CO}_{2}$ 分圧が高いほど高濃度の $\mathrm{HCO}_{3}$ 型地下水を生 成し得る。

\section{2 高電解質濃度地下水の成因について}

地すべり地の高濃度地下水の成因を探るためには, 陰 イオンに注目し, 陰イオンを供給する機構の解明が重要 である。佐藤・青木 ${ }^{10)}$ は, 新潟県の地すべり地内外の水 質データを整理し, 新鮮な地すべり地の地下水は古い地 すべり地や地すべり地外の水より, 電気伝導度が 10 倍以 上高いことを示した。高濃度地下水の陽イオンの起源は 岩石に求めることができる。陽イオン間の組成比の変動 は粘土鉱物によるイオン交換反応で説明できる。しかし， 大量の陽イオンと等価にある大量の陰イオンは, 基本的 には岩石中にその成分がないので岩石からは供給されな い。佐藤ほか ${ }^{11)}$ は, 空気中に放置した泥岩から比較的速 やかに $\mathrm{SO}_{4}{ }^{2-}$ が生成することを実験的に確認し, $\mathrm{SO}_{4}{ }^{2-}$ は泥岩中の黄鉄鉱の酸化に成因を求めた。松之山におい ても泥岩分布域に $\mathrm{SO}_{4}$ 型の地下水が多い(図一4)。一 方, $\mathrm{SO}_{4}{ }^{2-}$ の供給源として石高 $\left(\mathrm{CaSO}_{4} \cdot 2 \mathrm{H}_{2} \mathrm{O}\right)$ や硬石 高 $\left(\mathrm{CaSO}_{4}\right)$ を考えることもできる。地下水が石高に飽 和か不飽和かを判定するために, 図一 9 に地下水の石萵 に対する Saturation Index（S. I.）を示した。S. I. は次 式で表す。

$$
\text { S. I. }=\log \left(10^{-4.6} /\left[\mathrm{Ca}^{2+}\right] \times\left[\mathrm{SO}_{4}{ }^{2-}\right]\right)
$$

$10^{-4.6}$ は石膏の溶解度 (Appelo and Postma ${ }^{12)}$ ), $\left[\mathrm{Ca}^{2+}\right]$ と $\left[\mathrm{SO}_{4}{ }^{2-}\right]$ は地下水の $\mathrm{Ca}^{2+}$ と $\mathrm{SO}_{4}{ }^{2-}$ のモル濃度 $(\mathrm{mol} / \mathrm{l})$ である。図ー9をみると松之山地域の地下水は石高に不 飽和であり, 地下水が石高と平衡に共存していたとは考 えられない。佐藤ほか ${ }^{11)}$ のように, $\mathrm{SO}_{4}{ }^{2-}$ の起源は泥岩 中の黄鉄鉱の酸化に求めるのが妥当である。ならば, $\mathrm{SO}_{4}{ }^{2-}$ の生成には酸素の供給が不可欠である。 $\mathrm{SO}_{4}$ 型の 地下水が泥岩分布域の横孔ボーリングの水に多いのは, 酸素の多い地表近くで $\mathrm{SO}_{4}{ }^{2-}$ が生成したとする考えと 整合的である。水/岩石比にもよるが, 地表近くの破壊後
間もない新鮮な泥岩ほど $\mathrm{SO}_{4}{ }^{2-}$ 濃度が高い。松之山町の 天水越地区の地すべり地で平成元年に施工された横孔 ボーリングには $\mathrm{SO}_{4}{ }^{2-}$ 濃度が $1360 \mathrm{mg} / 1$ にも達する水 がある。

一方で, 高濃度 $\mathrm{Na}-\mathrm{HCO}_{3}$ 型の地下水の産出は松之山 地域をはじめとする新潟県内の第三紀層地すべり地の特 徵の一つである。木村 ${ }^{13)}$ は神戸層群の地すべり地にみら れる高濃度 $\mathrm{Na}-\mathrm{HCO}_{3}$ 型地下水の形成機構について, 基 岩である淡水成の凝灰質泥岩の溶出実験から, 置換性 $\mathrm{Na}^{+}$を含むモンモリロナイトと方解石 $\left(\mathrm{CaCO}_{3}\right)$ が共存 し,これらが雨水や地下水と反応することによって効果 的に高濃度 $\mathrm{Na}-\mathrm{HCO}_{3}$ 型地下水が生成するとした。松之 山地域では凝灭岩分布域, 泥岩分布域を問わず高濃度 $\mathrm{Na}-\mathrm{HCO}_{3}$ 型地下水が存在し, 中には $\mathrm{HCO}_{3}{ }^{-}$当量濃度 が $10 \mathrm{meq} / 1$ を超える地下水が存在する。凝灰岩および 泥岩は多量のスメクタイトとセメント物質として少量の 炭酸塩鉱物（ドロマイト）を含み, 条件は木村 ${ }^{13)}$ の見解 を支持する。しかし, 松之山地域をはじめとする新潟県 内の地すべり地の基岩は, 海成の泥岩であるため黄鉄鉱 を含んでおり, 木村 ${ }^{13)}$ と同様の条件下における溶出実験 では黄鉄鉱の酸化により, $\mathrm{SO}_{4}$ 型の水になってしまう。 佐藤 ${ }^{14)}$ が指摘したように, 黄鉄鉱が溶脱し, 風化が進行 した泥岩と反応して形成された水は, $\mathrm{SO}_{4}$ 型ではなく $\mathrm{HCO}_{3}$ 型となるが, 炭酸塩鉱物 (ドロマイト)やその他の 鉱物の溶脱も進行しているため, $\mathrm{HCO}_{3}$ - 濃度の高い地下 水の形成には不利である。

松之山地すべりにおいて, 高濃度 $\mathrm{Na}-\mathrm{HCO}_{3}$ 型地下水 が形成されるには, $\mathrm{CO}_{2}$ を溶かした水と比較的新鮮な岩 石とが還元的条件下で反応することが必要となる。つま り, 高濃度 $\mathrm{Na}-\mathrm{HCO}_{3}$ 型地下水は, 地表近くで黄鉄鉱の 酸化によって形成された $\mathrm{SO}_{4}$ 型の地下水に比べ, 還元的

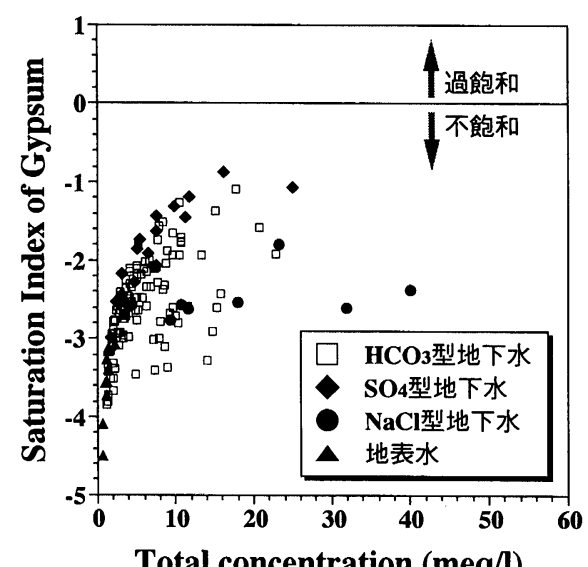

図ー9 Saturation Indexによる地すべり地地下水 の石高に対する飽和・不飽和の判定 


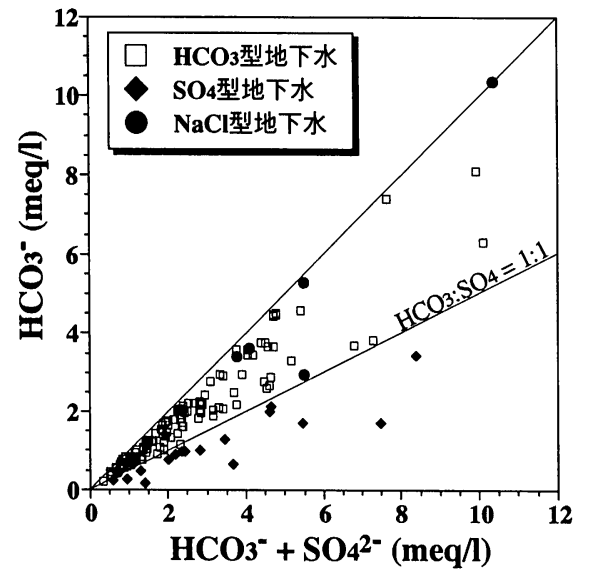

图-10 水質別の $\mathrm{HCO}_{3}{ }^{-}+\mathrm{SO}_{4}{ }^{2-}(\mathrm{meq} / \mathrm{l})$ と $\mathrm{HCO}_{3}{ }^{-}(\mathrm{meq} / \mathrm{l})$ の関係

な深い所で形成されなければならない。図ー10をみる と, $\mathrm{Na}-\mathrm{Cl}$ 型もふくめて $\mathrm{HCO}_{3}$ - 濃度が $4 \mathrm{meq} / 1$ 以上の 水は 2 つの例外を除き $\mathrm{SO}_{4}{ }^{2-}$ をほとど含まない。高濃 度 $\mathrm{Na}-\mathrm{HCO}_{3}$ 型地下水の形成場が $\mathrm{SO}_{4}{ }^{2-}$ を形成できな い条件下にあることを示唆している。例外の水は集水井 の構造上, 浅い $\mathrm{SO}_{4}$ 型の地下水と深い $\mathrm{Na}-\mathrm{HCO}_{3}$ 型地下 水が井戸の中で混合してしまったために形成されたので あろう。

筆者らは, 炭酸塩の溶解も含めて高濃度 $\mathrm{Na}-\mathrm{HCO}_{3}$ 型 地下水の形成には $\mathrm{CO}_{2}$ 分圧が重要な役割を果たすと考 えている。地すべり地の地下水の $\mathrm{pH}$ は 6〜8 の值が圧倒 的に多い。よって主要な炭酸物質は $\mathrm{HCO}_{3}$-であり, $\mathrm{pH}$ と $\mathrm{HCO}_{3}$ - 濃度から次のように $\mathrm{CO}_{2}$ 分圧を見積もること ができる。水に $\mathrm{CO}_{2}$ ガスが溶ける反応は次式のように表 される。

$$
\mathrm{CO}_{2}+\mathrm{H}_{2} \mathrm{O}=\mathrm{HCO}_{3}{ }^{-}+\mathrm{H}^{+}
$$

この反応の平衡定数を $K$ とすると,

$$
K=\left[\mathrm{H}^{+}\right]\left[\mathrm{HCO}_{3}^{-}\right] / \mathrm{PcO}_{2}
$$

となる。［］はモル濃度 $(\mathrm{mol} / \mathrm{l}), \mathrm{P}$ はガスの分圧であ

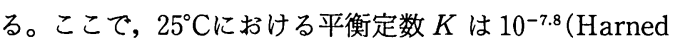
and Davis $\left.{ }^{15)}\right)$ であるから, $\mathrm{CO}_{2}$ 分圧は次式によって,

$$
\log \mathrm{PCO}_{2}=\log \left[\mathrm{HCO}_{3}{ }^{-}\right]-\mathrm{pH}+7.8
$$

となる。図-11に $\mathrm{pH}$ と $\mathrm{HCO}_{3}{ }^{-}$濃度から見樻もられた 地下水と平衡な $\mathrm{CO}_{2}$ 分圧を示した。松之山地すべり地域 の地下水の $\mathrm{CO}_{2}$ 分圧は $10^{-1.2} \sim 10^{-3.1}$ 気圧であり, $10^{-1.5}$ 〜 $10^{-2.5}$ 気圧の範囲のものが多い。これらは大気中の炭 酸ガスのおよそ 10 100 倍に相当する。最頻值は $10^{-2.1}$ ～10 $0^{-2.2}$ 気圧であり, 平均值は $10^{-1.96}$ である。岩石との反

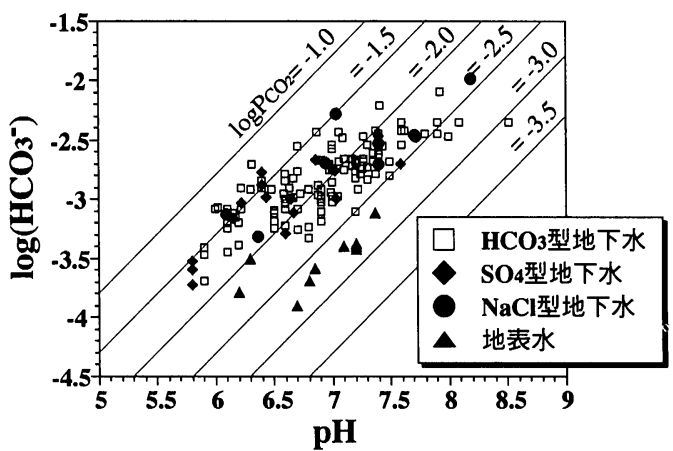

図ー11 $\mathrm{pH}$ と $\mathrm{HCO}_{3}$-モル濃度の関係による $\mathrm{CO}_{2}$ 分圧の見 積もり

応の結果生じた地下水の $\mathrm{CO}_{2}$ 分圧は, 反応の初期の $\mathrm{CO}_{2}$ 分圧と異なることがある。新たな $\mathrm{CO}_{2}$ の供給のない閉鎖 された条件では岩石との反応によって $\mathrm{CO}_{2}$ ガスが消費 され, 反応が進行した地下水の $\mathrm{CO}_{2}$ 分圧は, 反応の初期 段階の分圧より小さくなる。 $\mathrm{CaCO}_{3}$ (方解石) $-\mathrm{H}_{2} \mathrm{O}-$ $\mathrm{CO}_{2}$ の系を例に考えると, $\mathrm{CO}_{2}$ 分圧が $10^{-1.5}$ 気圧のとき $\mathrm{pH}$ は 4.6, $\left[\mathrm{HCO}_{3}^{-}\right]$は $10^{-4.6}(\mathrm{~mol} / \mathrm{l})$ である。方解石の 溶解は, 常に $\mathrm{CO}_{2}$ ガスの供給がある場合, 最終的に $\mathrm{pH}$ は 7.0, $\left[\mathrm{HCO}_{3}^{-}\right]$は $10^{-2.3}(\mathrm{~mol} / \mathrm{l})$ となり, $\mathrm{CO}_{2}$ 分圧は $10^{-1.5}$ 気圧と変わらない。新たな $\mathrm{CO}_{2}$ ガスの供給がない 場合, 最終的に $\mathrm{pH}$ は 7.7, $\left[\mathrm{HCO}_{3}^{-}\right]$は $10^{-2.7}(\mathrm{~mol} / \mathrm{l})$ と なり, $\mathrm{CO}_{2}$ 分圧は $10^{-2.6}$ 気圧に減少する。（例えば, Appelo and Postma $\left.{ }^{12)}\right)$ 。天然の岩石は多種の鉱物が共 存する複雑な系であり, 高濃度 $\mathrm{NaHCO}_{3}$ 型地下水のよ うに反応が進行した地下水から，反応の初期段階におけ る $\mathrm{CO}_{2}$ 分圧を知ることは困難である。

高濃度 $\mathrm{Na}-\mathrm{HCO}_{3}$ 型地下水は, $\mathrm{HCO}_{3}^{-}$モル濃度が高 いにもかかわらず, $10^{-1.5} \sim 10^{-2.2}$ 気圧程度の $\mathrm{CO}_{2}$ 分圧を 有するものがある。この解釈として次の 2 つが考えられ る。一つは $\mathrm{CO}_{2}$ について閉鎖している系で, 反応の初期 段階における $\mathrm{CO}_{2}$ 分圧は $10^{-1.5}$ 気圧よりもさらに高い 場合。もう一つは, 常に $10^{-1.5}$ 気圧程度の $\mathrm{CO}_{2}$ ガスが供 給され続ける開放した系で, 地下水と岩石とが反応した 場合である。 $\mathrm{CO}_{2}$ ガスの起源については, 高濃度 $\mathrm{Na}-$ $\mathrm{HCO}_{3}$ 型地下水が嫌気的条件で形成されたことと地下水 と平衡な $\mathrm{CO}_{2}$ 分圧が大気のそれより 10～100 倍大きい ことから, 有機物の分解あるいは地下深部から供給され る $\mathrm{CO}_{2}$ ガスのどちらかが起源である。後述するように $\mathrm{Na}-\mathrm{Cl}$ 型地下水の出現や地下水温の異常を考えあわせ ると, $\mathrm{CO}_{2}$ ガスは地下深部から供給されている可能性が ある。

\section{$6.3 \mathrm{Na}-\mathrm{Cl}$ 型地下水}

新潟県の地すべり地では, しばしば $\mathrm{Na}-\mathrm{Cl}$ 型の特異な 地下水が見出されている(例えば, 佐藤 ${ }^{14) 16)}$, 牧ほか ${ }^{17)}$ 
ぞ)。松之山地域の水梨地区では $\mathrm{Cl}^{-}$濃度が $1100 \mathrm{mg} / 1$ にも達する地下水がある。岩石中の $\mathrm{Cl}$ 含有量は極めて小 さいので, $\mathrm{Na}-\mathrm{Cl}$ 型地下水は前述した水一岩石相互作用 では説明できない。また，温帯湿潤な気候条件を考える と, 通常 $\mathrm{Cl}^{-}$濃度が $5 \sim 10 \mathrm{mg} / 1$ 程度の地下水が蒸発に よって $1000 \mathrm{mg} / \mathrm{l}$ 以上に濃縮されることはありえない。 $1000 \mathrm{mg} / 1$ 以上の $\mathrm{Cl}^{-}$濃度と松之山地域の地理的条件を 考えると，風送塩の影響も極めて小さい。前述のように $\mathrm{Na}-\mathrm{Cl}$ 型地下水の多くは, 泥岩地域のものであっても $\mathrm{SO}_{4}$-をほとんど含まないので（図ー10), 地表近くで形 成した浅い地下水ではない。 $\mathrm{Na}-\mathrm{Cl}$ 型地下水は地すべり 地に特徵的な水であって, 近傍の安定地には産しない。 第三紀層地すべり地の地下水の動きを考える上で極めて 重要である。

松之山は温泉地としても有名である。松之山温泉の水 質は $\mathrm{Cl}^{-}$濃度が $9000 \mathrm{mg} / 1$ 前後の $\mathrm{Na}-\mathrm{Cl}$ 型であり,メ夕 ンガスをともなう。鷹の湯 1 号井は深さ $170 \mathrm{~m}$ で $90^{\circ} \mathrm{C}$ の 温泉が間欠的に自噴している。大木ほか ${ }^{18)}$ はこれらの熱 水と地すべり・群発地震の関連性を指摘している。

$\mathrm{Na}-\mathrm{Cl}$ 型地下水が松之山温泉の水質に類似すること と, 断層の近傍に分布していることからみて, これらは 断裂を通って媣部から上昇してきた可能性が大きい。

\section{7 ．地すべり地地下水の水温}

図ー12に地すべり地における標高と水温の関係を示 した。線 A は新潟市の年平均気温から推定した任意の標 高における年平均気温。松之山地域の年平均気温とほほ 一致すると考えられる。地下水温は一般に年平均気温よ り, 1 2 ${ }^{\circ} \mathrm{C}$ 高いとされる (山本 ${ }^{199}$ ) ので, 線 B は線 A に $2{ }^{\circ} \mathrm{C}$ 加えた線である。図一 12 をみると,松之山地すべり地

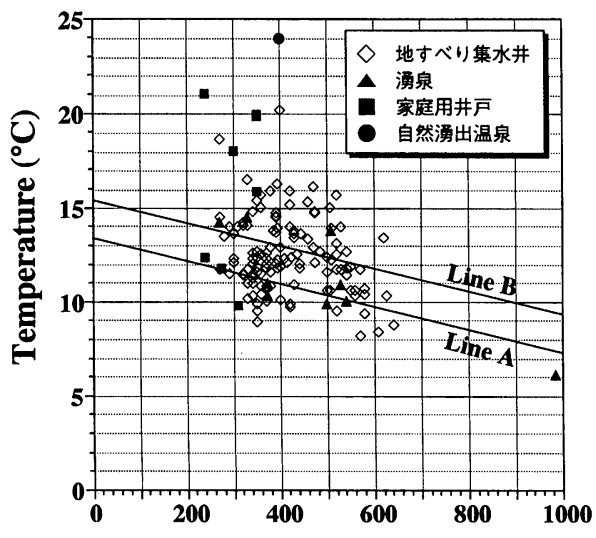

Altitude (m)

図ー12 松之山地すべり地でみとめられた異常高温地下水。 横軸は標高, 縦軸は水温。線 $\mathrm{A}$ は新潟市の年平均 気温の高度補正。線 $\mathrm{B}$ は線 $\mathrm{A}+2^{\circ} \mathrm{C}$
域の地下水は, 線 $\mathrm{B}$ よりも高い水温の地下水が多数存在 し，極端なものでは線 $\mathrm{B}$ よりも $7^{\circ} \mathrm{C} も$ 高い。いくつかの 井戸において，6月，8月，11月に水温を測定したとこ ろ，1〜 $2^{\circ} \mathrm{C}$ 季節変化がみられた。水温については今後 さらに詳しい調査を行う予定であるが，季節変化や測定 誤差などを考虑しても，松之山地すべり地には水温の高 い地下水が存在するとみられる。水温 $24^{\circ} \mathrm{C}$ の松之山湯田 温泉は, 現在の井戸の深さは $40 \mathrm{~m}$ であるが, 本来は自然 涌出していた温泉である。水温の異常は地下深部の熱水 に起因する熱流体（熱水あるいはガス）の影響と考えら れる。

\section{8.まとめ}

松之山地すべり地の地下水の水質は地質状況をよく反 映している。水質の特徵をまとめると以下の通りである。

1）電解質成分による大局的な水質の分布は次の通り である。

$\mathrm{Ca}-\mathrm{HCO}_{3}$ 型; 地すべりの頭部〜中央部付近。

$\mathrm{Na}-\mathrm{HCO}_{3}$ 型; 地すべりの中央部〜末端部付近。

$\mathrm{Ca}-\mathrm{SO}_{4}$ 型; 泥岩を基岩とする地すべりの頭部〜中 央部付近。

$\mathrm{Na}-\mathrm{SO}_{4}$ 型; 泥岩を基岩とする地すべりの中央部

末端部付近。

これらの地下水は地すべり頭部から末端部に向か うにつれて, 電解質濃度が高くなる傾向がある。 $\mathrm{Na}-\mathrm{Cl}$ 型; 断層の周辺。温泉。

2 ）凝灰岩分布域では $\mathrm{Ca}$ 型が多く，泥岩分布域では $\mathrm{Na}$ 型が多い。これは凝灰岩と泥岩の主に粘土鉱物 の組成の違いを反映している。

3 ) Ca 型に比べ $\mathrm{Na}$ 型の方が相対的に電解質濃度が 高い。全当量濃度が $30 \mathrm{meq} / \mathrm{l}$, 電気伝導度にして約 $1500 \mu \mathrm{S} / \mathrm{cm}$ 以上の異常に高い電解質濃度の地下水 は $\mathrm{NaCl}$ 型である。

4) $\mathrm{SO}_{4}$ 型の地下水は泥岩分布域に特徴的である。こ れは泥岩中の黄鉄鉱が酸素の豊富な地表近くで酸化 されることで生成される。 $\mathrm{SO}_{4}$ 型の地下水は浅い地 下水である。

5 ) 電気伝導度が $1000 \mu \mathrm{S} / \mathrm{cm}$ 以上の高濃度 $\mathrm{Na}^{-}$ $\mathrm{HCO}_{3}$ 型地下水は比較的高い $\mathrm{CO}_{2}$ 分圧のもとで嫌 気的還元的条件下で生成したと考えられる。高濃度 $\mathrm{Na}-\mathrm{HCO}_{3}$ 型地下水は深い地下水と考えられる。

6) $\mathrm{Na}-\mathrm{Cl}$ 型の地下水は地すべり地に特有であり, 近 傍の安定地にはみられない。 $\mathrm{Na}-\mathrm{Cl}$ 型の地下水は地 表から地下に浸透した水と岩石の相互作用では生じ ない。松之山温泉の水質に類似することと断層の近 くに分布することから，地下深部から断裂を通じて 上昇してきた水と考えられる。 
7 ) 水温の高い地下水が存在する。これらは地下深部 の熱水の影響をうけている可能性がある。

\section{謝 辞}

研究をすすめるに当たり, 新潟県安塚土木事務所, 同 県東頸城農地事務所, 同県上越林業事務所, 高田営林署, 松之山町役場の方々にいろいろお世話いただいた。新潟 県安塚土木事務所長の山岸俊男氏（現在: 同県土木部道 路建設課長）には特にお世話になった。野外調查では安 塚町の新保馨さん宅に宿泊させていただいた。新潟大学 理学部の吉村尚久教授と院生の山田和生氏（現在: 日本 工営）には鉱物分析・同定の便宜をはかっていただいた。 本研究に(䝧)砂防・地すべり技術センター研究開発助成金 と文部省科学研究費一般研究 $\mathrm{B}$ (代表: 宮下純夫, 課題番 号 06452092）の一部を使用させていただいた。以上の 方々に記して感謝申し上げます。

\section{参考文献}

1 ）天野和孝 (1991): 松之山町史編纂委員会編「松之山町史」, 松之山町, 11-30

2 ）津田禾粒・白井健裕・長谷川美行・新川 公 (1984): 土 地分類基本調査「松之山温泉」, 新潟県, 33-52

3 ) Garrels R. M. and Christ C. L. (1965): Solutions, Minerals and Equilibria. Freeman and Cooper. $450 \mathrm{pp}$

4) 佐藤 修 (1993): 地すべり地における地下水水質調査法 (その 1)一現地調查とデー夕の整理一, 地すべり技術, 20 巻 1 号, $11-23$

5 ) 佐藤 修 (1993): 地すべり地における地下水水質調査 (その 2)－地すべり地地下水の水質形成過程一, 地すべ
り技術, 20 巻 2 号, $18-28$

6 ）佐藤 修 (1994): 地すべり地における地下水水質調查法 (その 3) 一地すべり地地下水の水質形成過程と調査実 例一, 地すべり技術, 20 巻 3 号, 16-26

7 ) 吉岡龍馬 (1990): 地すべりと水一地球化学的調查（その 1), 地下水学会誌, 32 巻 3 号, 147-162

8 ) 吉岡龍馬 (1990): 地すべりと水一地球化学的調査（その 2), 地下水学会誌, 32 巻 3 号, 253-272

9 ) 吉岡龍馬・金井忠一（1975）: 地すべり地地下水の炭酸ガ ス分圧について, 京大防災研年報, 18 号 $\mathrm{B}, 1-12$

10）佐藤 修・青木 滋 (1990): 地すべり地内外の水質の特 徵一第三系泥岩地帯の地すべりを例としてー, 地すべり， 27 巻 1 号, $27-33$

11）佐藤 修・青木 滋・鈴木幸治（1983）：虫龟地すべり地 の地下水のアニオンの起源一地すべり地の陸水の水質 3 -, 新潟大災害研年報, 第 5 号, 33-42

12) Appelo C. A. J. and Postma D. (1992): Geochemistry, groundwater and pollution. A. A. Balkema. $536 \mathrm{pp}$

13）木村耕治 (1990): 神戸層群の地すべり地に存在する高濃 度 $\mathrm{Na}-\mathrm{HCO}_{3}$ 地下水の形成機構, 地下水学会誌, 32 巻 1 号, 5-16

14）佐藤 修 (1981)：地すべり地の陸水の水質 1. 虫龟・ 高倉地すべり, 新潟大災害研年報, 第 3 号, 47-58

15) Harned H. S. and R. Davis, Jr (1943): The ionization constant of carbonic acid in water and the solbility of carbon dioxide in water aqueous salt solution from 0 to $50^{\circ} \mathrm{C}$. J. Amer. Chem. Soc. $65,2030-2037$

16）佐藤 修 (1982)：地すべり地の陸水の水質 2. 濁沢・ 上馬場地すべり, 新潟大災害研年報, 第 4 号, 77-85

17）牧 隆正・富田利保 (1965): 松之山地すべり地带陸水の 水質特性について, 地すべり, 1 巻 3 号, $1-7$

18）大木靖衛・佐藤 修・青木 滋 (1992): 北部フォッサマ グナのジオプレッシャー熱水系に起因する地震と地すべ り, 月刊地球, 号外 No. 5, 121-125

19）山本荘毅（1992）：地下水水文学, 共立出版, $228 \mathrm{pp}$ （原稿受理日 平成 6 年 12 月 12 日） 
可能性線形回帰分析による地雿時の切土のり面・斜面の崩壊危険度判定の検討

「地すへり」Vol. 32, No. 3 (通巻第 123 号) pp. 1 9, 1995 年（平成 7 年）12月

寺田秀樹, 船山 淳, 大浦二朗, 須原 茂

可能性線形回帰分析により, 地震時の斜面崩壊の危険度評価を試みた。その結果, 表層崩壊において地震加速 度に影響される要因は主に地形要因であるとするモデルが同定された。他の地震による崩壊地を適用したところ, 適用の幅が小さいという問題点が指摘された。

An Estimation Method of Running Down Distance of Slope Failure Debris by a Fuzzy Inference Method Based on L-R Type Membership Function 「地すへり」Vol. 32, No. 3 (通巻第 123 号) pp. 10 16, 1995 年（平成 7 年）12 月

Hiroyuki Yoshimatsu and Saburo NAKAMURA

がけ崩れの崩土の到達距離に関する災害データは, 災害直後に収集されることもあってファジィネスを有して いる。これら災害データについて到達距離に関与する要因を L-R 型メンバーシップ関数で表わし，デル夕則によ る学習結果のファジィ推論より崩土の到達距離を予測する手法を提案した。この手法は学習機能を有することよ り汎化性の高い手法であるとともに解析に使用する要因の曖昧性が検討できることを明らかにした。

\section{くさび杭設計のための試論}

「地すべり」Vol. 32, No. 3 (通巻第 123 号) pp. 17 23, 1995 年（平成 7 年）12月 小島義孝, 山田言政, 渡邉直人, 速水博秀

くさび杭の新しい理論による設計法を検討した。この設計法では杭に作用する横荷重と移動層および不動層に 発生する地盤反力の釣り合い,さらに移動層スライスに於けるカとモーメントの釣り合いを考慮した理論にもと づき設計式を導いた。このため杭のたわみ方程式として, 移動層に発生する地すべり変位を考慮した式を用いた。 また斜面の安定評価理論によって杭に作用する横荷重を算定した。なお杭に作用する横荷重は従来の設計法と同 様, 移動層, 不動層の境界に作用する集中力を仮定した。また杭設置後の斜面の全体安全率の判定法についても 検討を行った。

\section{第三紀層地すべりの移動解析}

「地すべりVol. 32, No. 3 (通巻第 123 号) pp. 24〜31，1995 年（平成 7 年）12月 丸山清輝

本文では，第三紀層地すべりにおける地すべり動態観測結果をもとに，間隙水圧及び地下水位と地すべり日移 動量との時系列的な関係について検討した。その結果, 間隙水圧及び地下水位の変化による地すべり日移動量の 時系列変化は，粘土のクリープ特性をもとにした式により求められることが分かった。

新潟県松之山地すへり地域の地下水の水質について

「地すへり」Vol. 32, No. 3 (通巻第 123 号) pp. 32〜40, 1995 年（平成 7 年） 12 月

渡部直喜, 㖪津史也, 大木靖街, 佐藤 修

新潟県松之山地すべり地域の地下水の水質を調査・分類・整理し, 水一岩石相互作用の見地から地下水の形成過 程を考察した。大部分の地下水の水質は, 母岩の特徵をよく反映しており, 地下に浸透した水と母岩との水一岩石 相互作用によって形成された。一方, 水と母岩との反応では形成できない $\mathrm{Na}-\mathrm{Cl}$ 型の地下水もみとめられる。 $\mathrm{Na}-\mathrm{Cl}$ 型の地下水は松之山温泉の泉質に類似し, 断層の近傍に分布する傾向にある。また, 高い $\mathrm{CO}_{2}$ 分圧の条件 下で形成された地下水や水温の高い地下水もみとめられる。松之山地域の地すべり地の一部の地下水には, 断裂 を通じて上昇してくる地下深部の熱水の寄与がある。 